\title{
The growth of grass carp (Ctenopharyngodon idella) fed on Azolla
}

\author{
Pertumbuhan ikan koan (Ctenopharyngodon idella) yang diberi pakan Azolla \\ Desmianti Babo ${ }^{1 *}$, Henneke Pangkey ${ }^{2}$, and Erly Kaligis ${ }^{2}$ \\ ${ }^{1}$ Program Studi Ilmu Perairan, Program Pascasarjana Universitas Sam Ratulangi. Jln. Kampus Unsrat Kleak, \\ Manado 95115, Sulawesi Utara, Indonesia. \\ ${ }^{2}$ Fakultas Perikanan dan Ilmu Kelautan, Universitas Sam Ratulangi. Jl. Kampus Unsrat Bahu, Manado 95115, \\ Sulawesi Utara, Indonesia. \\ *E-mail:desmibabo@gmail.com
}

\begin{abstract}
This research was done for two months to analyze the growth of grass carp (length $7.00-10.00 \mathrm{~cm}$ and initial weight 5.00-10.00 gr) fed on pellets with azolla meal that replaces fish meal on different levels and fresh azolla. Experimental research methodology used Completely Randomized Design. The best result was showed on treatment using fresh azolla. This is to confirm that using azolla on young stages for culture of grass carp can be done to reduced cost of production.
\end{abstract}

Keywords: azolla; fish feed; grass carp.

Abstrak: Penelitian dilakukan selama dua bulan untuk menganalisis pertumbuhan ikan koan (berukuran panjang 7,00-10,00 cm dan berat awal 5,00-10,00 gr) yang diberi pakan pelet dan subtitusi tepung azolla terhadap tepung ikan dengan kadar yang berbeda, serta azolla segar. Metode penelitian secara eksperimental, menggunakan Rancangan Acak Lengkap. Hasil terbaik ditunjukkan pada perlakuan dengan pakan azolla segar. Hasil ini mengkonfirmasi, bahwa penggunaan azolla dapat dilakukan untuk budidaya ikan grass carp pada stadia benih dalam menekan biaya produksi.

Kata-kata kunci: azolla; pakan ikan; ikan koan.

\section{PENDAHULUAN}

Dalam kegiatan akuakultur, penyediaan pakan bagi biota budidaya merupakan faktor yang sangat menentukan terhadap untung rugi usaha ini. Saat ini di Indonesia, penyediaan pakan masih menghadapi kendala dalam hal ketersediaan bahan baku yang bersifat murah, berkualitas baik, tersedia dalam jumlah yang cukup, tepat waktu, dan berkesinambungan, serta tidak bersaing dengan kebutuhan manusia yang dapat mempengaruhi harga pakan tersebut.

Bahan bersumber protein, sebagai salah satu unsur dalam penyusunan pakan ikan, sebagian besar masih berasal dari tepung ikan. Di Indonesia, tepung ikan masih diimpor dari luar negeri karena produksi dalam negeri belum mampu memenuhi kebutuhan yang ada. Impor tepung ikan Indonesia di tahun 2000 mencapai 87.275 ton dengan nilai US\$ 39.483 juta. Selanjutnya, pada tahun 2012, permintaan akan bahan ini semakin meningkat yaitu sekitar 100.000-120.000 ton per tahun (Anonimous, 2012). Untuk itu, pencarian sumbersumber bahan baku protein, sebagai salah satu ransum pada pakan ikan, perlu terus dilakukan.
Beberapa hasil penelitian telah menunjukkan bahwa azolla dapat menjadi bahan subtitusi alternatif untuk tepung ikan. Tanaman azolla potensial digunakan sebagai pakan karena banyak terdapat di perairan tenang seperti danau, kolam, rawa dan persawahan (Haetami and Sastrawibawa, 2005). Tumbuhan ini memiliki karakter pertumbuhan dan perkembangan yang cepat, yaitu dua kali lipat setiap 3-5 hari (Brotonegoro and Abdulkadir, 1976 dan Abdulkadir et al., 1998 dalam Handajani, 2006). Moore (1969) dalam Handajani (2006) memper-kirakan pada setiap satu hektar sawah dapat diproduksi 50 ton azolla basah. Namun pemanfa-atan azolla di Indonesia, termasuk di Sulawesi Utara, belum dilakukan. Untuk itu, penelitian ini dilakukan dengan tujuan untuk mengetahui peman-faatan azolla terhadap pertumbuhan ikan koan (Ctenopharyngodon idella).

\section{MATERIAL DAN METODA}

\section{Tempat dan Waktu Penelitian}

Kultur azolla dilakukan di Balai Budidaya

Air Tawar (BBAT) Desa Tatelu, Minahasa Utara. 
Pembuatan pakan dilaksanakan di Laboratorium Teknologi Akuakultur, Fakultas Perikanan dan Ilmu Kelautan, Unsrat Manado. Penelitian untuk melihat pertumbuhan ikan koan yang diberikan azolla dilakukan di area perkolaman Desa Tatelu Kabupaten Minahasa Utara.

\section{Kultur azolla}

Kolam yang digunakan untuk kultur dibersihkan terlebih dahulu, dikeringkan serta diairi secukupnya (sebanyak $1 / 4$ dari volume kolam). Selanjutnya diberikan pupuk organik sebanyak 5 $\mathrm{mg} / \mathrm{L}$ air. Dua hari setelah pupuk diberikan, dimasukkan azolla (500 gram) ke dalam kolam. Setelah azolla tumbuh menutupi permukaan air, azolla dipanen dan dikeringkan di bawah sinar matahari. Pengeringan dilakukan selama 2-3 hari hingga azolla benar-benar kering dan mudah hancur saat digenggam. Kultur dilakukan selama beberapa kali, hingga mendapatkan persediaan untuk pembuatan tepung azolla dan untuk pakan azolla segar.

\section{Pembuatan pakan}

Pakan uji yang digunakan adalah pellet dengan penambahan azolla sebanyak $0 \%, 20 \%$, $30 \%$, 40\%, dan $50 \%$ yang disubstitusikan dengan tepung ikan serta pemberian azolla segar kepada ikan uji.

\section{Rancangan penelitian}

Sebanyak 180 ekor ikan koan (Ctenopharyngodon idella) berukuran panjang 7,00$10,00 \mathrm{~cm}$ dan berat awal 5,00-10,00 gram ditebarkan ke dalam 18 kantong jaring berukuran 0,5 m x 0,5 m x 1,5 m (panjang x lebar x tinggi), dengan kepadatan 10 ekor per kantong jaring. Ikan koan dipelihara selama 8 minggu. Pemberian pakan dilakukan dengan frekuensi dua kali sehari, yaitu pagi dan sore hari, pada pukul 07.00-08.00 WITA dan 15.00-16.00 WITA. Banyaknya pakan yang diberikan yakni sebanyak 4\% dari total berat tubuh ikan per hari. Pemberian pakan azolla segar kepada ikan uji dilakukan secara ad libitum.

Pengamatan pertumbuhan ikan dan pengumpulan data dilakukan setiap dua minggu sekali selama delapan minggu. Pengukuran dilakukan pada sore hari, meliputi ukuran panjang serta berat ikan. Parameter kualitas air yang diukur yakni suhu, $\mathrm{pH}$, dan DO yang dilakukan seminggu sekali pada pagi hari selama kegiatan penelitian berlangsung.

Rancangan percobaan menggunakan Rancangan Acak lengkap (RAL), dan uji statistik yang digunakan adalah analisis keragaman (ANOVA), serta uji lanjut dengan BNT dan Duncan. Beberapa variabel yang diamati dalam penelitian adalah pertumbuhan mutlak (Zonneveld et al., 1991), pertumbuhan panjang (Effendie, 1997), pertumbuhan Nisbi (Effendie, 1997), rasio konversi pakan (FCR) (Effendie, 2004), dan tingkat kelangsungan hidup (Effendie, 1997).

\section{HASIL DAN PEMBAHASAN}

Hasil dari pertumbuhan ikan grass carp yang diberi pakan azolla dapat dilihat pada Tabel 1. Hasil penelitian menunjukkan bahwa pertumbuhan mutlak paling tinggi terlihat pada perlakuan $\mathrm{F}$, dengan capaian rata-rata pertumbuhan yakni 7,19 gram, kemudian berturut-turut oleh perlakuan B (3,23 gram), perlakuan A (2,96 gram), perlakuan C (0,67 gram), perlakuan D $(0,32$ gram $)$, dan perlakuan E (0,34 gram).

Hasil analisis ragam (ANOVA) menunjukkan bahwa pemberian pakan memberikan pengaruh

Tabel 1. Pertumbuhan ikan koan (Ctenopharyngodon idella) yang diberi pakan azolla

\begin{tabular}{lcccccc}
\hline \multicolumn{1}{c}{ Parameter/Perlakuan } & A & B & C & D & E & F \\
\hline Jumlah ikan (ekor) & 10 & 10 & 10 & 10 & 10 & 10 \\
Waktu (bulan) & 2 & 2 & 2 & 2 & 2 & 2 \\
Berat awal (gr) & 6,66 & 6,54 & 6,28 & 6,35 & 6,50 & 6,37 \\
Berat akhir (gr) & 9,62 & 9,77 & 6,96 & 6,67 & 6,84 & 13,56 \\
Pertumbuhan mutlak (gr) & 2,96 & 3,23 & 0,67 & 0,32 & 0,34 & 7,19 \\
Pertumbuhan panjang (cm) & 1,12 & 1,20 & 0,55 & 0,38 & 0,38 & 2,37 \\
Pertumbuhan nisbi (\%) & 44,37 & 49,41 & 10,70 & 4,99 & 5,25 & 112,74 \\
FCR & 5,47 & 4,76 & 20,37 & 44,39 & 41,26 & 28,73 \\
SR & 100 & 96,67 & 100 & 83,33 & 86,67 & 100 \\
\hline Suhu (C) & \multicolumn{7}{c}{$24,2-25,8$} \\
pH & \multicolumn{7}{c}{$5,4-6,2$} \\
\hline DO (mg/L) & \multicolumn{7}{c}{50} \\
\hline
\end{tabular}


yang sangat berbeda nyata, di mana pada uji lanjut, baik pada BNT maupun pada Duncan menunjukkan perlakuan $\mathrm{F}$ sangat berbeda nyata dengan kelima perlakuan lainnya, sedangkan perlakuan B dan A memberikan pengaruh yang sama, demikian pula pada perlakuan C, E dan D. Namun untuk perlakuan $\mathrm{B}$ dan $\mathrm{A}$, menunjukkan adanya perbedaan yang sangat nyata dengan perlakuan C, E dan D.

Sama halnya pada uji pertumbuhan mutlak, pemberian pakan azolla segar terhadap ikan uji juga memberikan pertambahan panjang yang lebih baik. Perlakuan $\mathrm{F}$ menunjukkan nilai tertinggi, diikuti oleh perlakuan $\mathrm{B}$ dengan rata-rata pertumbuhan panjang $1,2 \mathrm{~cm}$, perlakuan $\mathrm{A}(1,12 \mathrm{~cm})$ dan perlakuan $C(0,55 \mathrm{~cm})$. Sedangkan untuk perlakuan $\mathrm{D}$ dan perlakuan $\mathrm{E}$ adalah sepanjang $0,38 \mathrm{~cm}$. Hasil analisis ragam untuk pertumbuhan panjang menunjukkan nilai F-hitung lebih besar dari F-tabel pada taraf $5 \%$ dan $1 \%$.

Pada hasil uji lanjut, baik BNT maupun Duncan, memperlihatkan perlakuan $\mathrm{F}$ sangat berbeda nyata dengan perlakuan A, B, C, D, dan E. Rata-rata pertambahan panjang pada perlakuan $\mathrm{F}$ adalah 2,37 cm. Perlakuan A dan B memberikan pengaruh yang sama terhadap pertambahan panjang ikan $(1,12-1,20 \mathrm{~cm})$. Perlakuan A dan B juga sangat berbeda nyata dengan perlakuan C, E, dan D. Dari hasil ini terlihat subtitusi tepung azolla terhadap tepung ikan, mempengaruhi pertumbuhan panjang ikan uji.

Pertumbuhan nisbi juga memberikan hasil yang sama dengan pertumbuhan mutlak dan pertumbuhan panjang di mana perlakuan $F$ memberikan pengaruh yang tertinggi. Diikuti oleh perlakuan $\mathrm{B}$ dan $\mathrm{A}$, perlakuan $\mathrm{C}$, D, dan $\mathrm{E}$ mengalami pertumbuhan yang melambat. Hasil perhitungan pertumbuhan nisbi untuk perlakuan $\mathrm{F}$ adalah di atas $100 \%$, diikuti oleh perlakuan B dengan rata-rata pertumbuhan nisbi $49,41 \%$, perlakuan A $(44,37 \%)$ dan C (10,70\%); sementara pertumbuhan nisbi terendah yaitu pada perlakuan $\mathrm{E}$ $(5,25 \%)$ dan D (4,99\%). Hasil uji lanjut menunjukkan, bahwa perlakuan $\mathrm{F}$ memberikan pertumbuhan nisbi yang terbaik.

Hasil yang diperoleh untuk rasio konversi pakan memperlihatkan, bahwa perlakuan A sebesar 5,47, B sebesar 4,76, C sebesar 20,37, D sebesar 44,39, E sebesar 41,26, dan F sebesar 28,73. Sedangkan hasil untuk tingkat kelangsungan hidup, untuk perlakuan A sebesar $100 \%$, B sebesar $96,67 \%$, C sebesar $100 \%$, D sebesar $83,33 \%$, E sebesar 86,67\%, dan $\mathrm{F}$ sebesar $100 \%$. Hasil pengukuran suhu berkisar $24,2-25,8^{\circ} \mathrm{C}$, $\mathrm{pH}$ sebesar 7 , dan kelarutan oksigen berada pada kisaran 5,4$6,2 \mathrm{mg} / \mathrm{L}$.
Menurut Suresh and Mandal (2002) serta Nas (1976) dalam Hariadi et al. (2005), bahwa memang makanan utama ikan koan berupa rerumputan air dan berbagai jenis tanaman air seperti Hydrilla sp., Eichhornia crassipes, Azolla sp., Lemna sp. dan Salvina sp.. Diantara semua jenis tumbuhan air, azolla paling disukai oleh ikan ini. Untuk ekosistim perairan seperti di Sulawesi Utara, sangat mudah untuk ditemui atau bahkan dibudidayakan tumbuhan air ini. Dari segi nutrisipun, azolla memiliki nilai nutrisi yang baik, yaitu protein sebanyak $21,9 \%$ dan lemak sebanyak 3,8\% (Mandal et al., 2010 dan Asadujjaman et al., 2014). Alalade and Iyayi (2006) menyatakan, bahwa azolla memiliki kandungan asam amino yang lengkap.

Selanjutnya dinyatakan oleh Setlikova and Adamek (2004) dan Majhi et al. (2006), bahwa ikan koan dan tilapia (Oreochromis spp.), seperti Tilapia rendalli (T. melaiopleura) dan $T$. zillii yang paling mampu untuk memanfaatkan nutrisi dari tumbuhan air. Hal ini sesuai dengan hasil yang diperoleh dalam penelitian ini. Dari beberapa perlakuan yang ada, perlakuan dengan memberikan azolla yang segar kepada ikan koan memberikan hasil yang terbaik (perlakuan F). Ikan koan dengan panjang 6-15 $\mathrm{cm}$ yang dipelihara pada suhu 21-26 ${ }^{\circ} \mathrm{C}$, mampu memakan tumbuhan air hingga $6-10 \%$ dari berat badan per hari (Woynavorich, 1968 dalam Cudmore and Nicholas, 2004).

Kebanyakan bahan konvensional, terutama tepung ikan dan tepung kedele, merupakan bahan yang akan semakin langka dan mahal bagi para pembudidaya ikan yang mengelola usaha mereka secara ekstensif di mana hal ini sangat menekan keuntungan yang diperoleh. Namun belakangan ini, terdapat banyak usaha yang dilakukan secara serius untuk menemukan bahan-bahan non-konvensional sebagai elemen dalam pakan ikan. Beberapa jenis tumbuhan penting yang dapat digunakan sebagai bahan dalam pakan ikan, antara lain, ialah Ottelia alismoides, Nymphoides indica, Elodea canadensis, Potamogeton pectinatus, Myriophyllum spicatum, Trapa bispinosa, Ipomoea aquatica, Ceratophyllum demersum, Salvinia cuculata, Pistia strateotes dan Eichhornia crassipes. Keuntungan lain dengan menggunakan bahan tersebut di atas, yaitu para pembudidaya ikan dapat menghasilkan produk organik yang belakangan ini semakin dicari, dan juga hal ini dapat meningkatkan keuntungan para pembudidaya ikan.

Penggunaan azolla sebagai tepung yang ditambahkan ke dalam formula pakan menggantikan tepung ikan juga memberikan hasil yang baik. Pada perlakuan B, dengan mensubsitusi 20\% tepung azolla, memberikan pertumbuhan yang lebih baik 
dibandingkan pada perlakuan A yang memiliki ransum $100 \%$ tepung ikan. Hasil yang sama diperoleh dari penelitian Nobuyuki and Shunji (2001) pada ikan Tilapia nilotica yang diberi pakan Azolla filiculoides. Gangadhar et al. (2015) menyatakan, bahwa pemberian Azolla pinnata sebagai subsitusi sampai $40 \%$ kepada Labeo fimbriatus (sejenis ikan mas) (berat awal \pm 5 gr dan panjang $\pm 7 \mathrm{~cm}$ ) dapat menekan biaya produksi sampai $24,48 \%$. Akan tetapi untuk budidaya ikan koan pada berat awal \pm 6 gram, berdasarkan hasil penelitian ini, sebaiknya diberikan pakan azolla segar, untuk menekan biaya produksi bagi para pembudidaya ikan grass carp. Namun, penelitian lanjut mengenai nilai nutrisi dari berbagai spesis azolla, yang berhubungan dengan umur azolla dan tingkat stadia ikan dalam memanfaatkan azolla segar serta sebagai bahan subsitusi, masih perlu dilakukan.

Parameter kualitas air yang tercatat tidak memberi pengaruh kepada pertumbuhan ikan uji, bahkan pemberian pakan azolla baik dalam bentuk pelet maupun dalam bentuk segar tidak mengganggu pertumbuhan ikan ini. Nilai parameter suhu air pada penelitian ini berada pada kisaran $24,2-25,8{ }^{\circ} \mathrm{C}$. Masser (2002) menyatakan, ikan grass carp makan secara optimum pada suhu $21-30{ }^{\circ} \mathrm{C}$. Garner et al. (2013) menyatakan, bahwa ikan grass carp dapat hidup dengan baik pada kisaran suhu $24,7-27,8{ }^{0} \mathrm{C}$. Kisaran optimum bagi parameter $\mathrm{pH}$ untuk kultur ikan grass carp menurut Cudmore and Mandrak (2004) adalah berkisar 5-9. Nilai pH yang terukur selama penelitian ini adalah rata-rata 7 . Pada umumnya, golongan ikan cyprinidae sangat mampu untuk hidup pada kondisi kandungan oksigen yang rendah, yaitu sampai $3 \mathrm{mg} / \mathrm{L}$ (Huet, 1972). Hasil pengukuran kandungan oksigen pada penelitian ini adalah berkisar 5,4-6,2 mg/L.

\section{KESIMPULAN}

Azolla dapat dikonsumsi oleh ikan koan (Ctenopharyngodon idella) secara segar pada stadia umur tertentu, sehingga penggunaan tumbuhan air ini dapat membantu para pembudidaya ikan dalam upaya menekan biaya produksi.

\section{REFERENSI}

ALALADE, O.A. and IYAI, E.A. (2006) Chemical Composition and the Feeding Value of Azolla (Azolla pinnata) Meal for Egg-Type Chicks.
International Journal of Poultry Science, 5(2), pp. 137-141.

ANONIMOUS (2012) Duh tepung Ikan Saja kok Impor. Kabar Bisnis Indonesia: Budidaya Ikan. budidaya-ikan.com/duh-tepung-ikan-saja-kokimpor/.15/10/2012.

ASADUJJAMAN, M., BISWAS, S., MANIRUJJAMAN, M., RAHMAN, M. and HOSSAIN, M. (2014) Determination of Protein, Lipid and Carbohydrate Contents of Conventional and Non-Conventional Feed Items Used in Carp Polyculture Pond. Fish. Aquac. J., 5, 4, p. 2-5.

CUDMORE, B., and MANDRAK, N. (2004) Biological Synopsis of Grass Carp (Stenopharyngodon idella). Canadian Manuscript Report of Fisheries and Aquatic Science. Burlington, Canada.

EFFENDIE, M.I. (1997) Biologi Perikanan. Yayasan Pustaka Nusantara. Yogyakarta. Hal. 163-164.

EFFENDIE, M.I. (2004) Pengantar Akuakultur. Penebar Swadaya. Jakarta.

GANGADHAR, B., SRIDHAR, N., SAURABH, S., RAGHAVENDRA, C.H., HEMAPRASANTH, K.P., RAGHUNATH, M.R., and JAYASANKAR, P. (2015) Effect of azolla-incorporated diets on the growth and survival of Labeo fimbriatus during fry to fingerling rearing. Cogent Food \& Agriculture, p. 2-8.

GARNER, A.B., THOMAS, J.K., KENNETH, L.M., and BARWICK, D.H. (2013) Highdensity grass carp stocking effects on a reservoir invasive plant and water quality. J. Aquat. Plant Manage, 51, p. 27-33

HAETAMI and SASTRAWIBAWA (2005) Evaluasi Kecernaan Tepung Azolla dalam Ransum Ikan Bawal Air Tawar (Colossoma macropomum). Jurnal Bionatura, Vol. 7 No 3. Hal. $225-233$.

HANDAJANI, H. (2006) Pemanfaatan Tepung Azolla Sebagai Penyusun Pakan Ikan Terhadap Pertumbuhan dan Daya Cerna Ikan Nila Gift (Oreochromis sp). Jurnal: Lembaga Penelitian Universitas Muhammadiyah Malang. Vol. 9(2b). Hal. 6-13.

HARIADI, B. and HARYONO, A.U.S. (2005) Evalusai efisiensi pakan dan efisiensi protein pada ikan kerapu (Ctenopharyngodon idella Val.) yang diberi pakan dengan kadar karbohidrat dan energi yang berbeda. Jurnal Ichtyos, 4(2): Hal.88-92.

MAJHI, S.K., DAS, A., and MANDAL, B.K. (2006) Growth Performance and Production of 
Organically Cultured Grass Carp Ctenopharyngodon idella (Val.) Under MidHill Conditions of Meghalaya, North Eastern India. Turkish Journal of Fisheries and Aquatic Sciences, 6, p.105-108.

MANDAL, R.N., DATTA, A.K., SARANGI, N., and MUKHOPA, P.K. (2010) Diversity of aquatic macrophytes as food and feed components to herbivorous fish - A Review. Indian J. Fish., 57, 3, p. 65-73.

MASSER, M.P. (2002) Using Grass Carp in Aquaculture and Private Impoundments. SRAC Publication No. 3600. 4 p.

NOBUYUKI, S. and SHUNJI, K. (2001) Culture of Azolla in a Pond, Nutrient Composition, and Use as Fish Feed. Soil Sci. Plant Nutr., 47, I, p. 27-34.
SETLIKOVA, I. and ADAMEK, J. (2004) Feeding selectivity and growth of Nile tilapia (Oreochromis niloticus) fed on temperate of zone aquatic macrophytes. Czeck J. Animal Sci., 49, p. 271-278.

SURESH, V. R. and MANDAL, B.K. (2002) Growth and feed utilization of grass carp fingerlings. Indian J. of Fisheries. Vol 49 (2). P. 155-206.

ZONNEVELD, N., E. A. HUISMAN., and BOON, H.J. (1991) Prinsip-prinsip Budidaya Ikan. Gramedia Pustaka Utama. Jakarta.

Diterima: 30 Desember 2015 Disetujui: 3 Februari 2016 